\title{
REVISITING THE ICONIC: THE EXCAVATION OF THE REELFITZ PIT ENGINE AND THE NEWCOMEN STEAM ENGINE IN CUMBERLAND, UK
}

\section{DAVID GEORGE \& MICHAEL NEVELL}

\section{SUMMARY}

Examples of excavated $18^{\text {th }}$ century stationary steam engine sites are very rare in Britain. This article records the rescue excavations ahead of road-building works of one such site in 1974-5 at Reelfitz Pit in Little Clifton, Cumberland. The Reelfitz Pit pumping engine was built around 1780 and abandoned in 1781. The remains uncovered show that the site had two external boilers and a narrow engine house with a cylinder on the ground floor. The excavation uncovered three engine parts from within the engine house: the piston flange from the cylinder, the connecting link from the piston rod to the beam and one of the chain links which fitted into the piston head. The current work discusses the site in terms of the development of the West Cumberland coal field and in the context of the surviving $18^{\text {th }}$ century Newcomen engines.

\section{INTRODUCTION}

L.T.C. Rolt described the Newcomen or more properly the atmospheric steam engine as one of the prehistoric forefathers of the classic steam engines of the Industrial Revolution. Only a few $18^{\text {th }}$ century beam engine houses remain standing in Britain, even fewer $18^{\text {th }}$ century Newcomen engines survive in the early $21^{\text {st }}$ century, and there are an equally small number of $18^{\text {th }}$ century Newcomen steam engine sites which have been excavated in the UK. Amongst these rare sites is the Reelfitz Pit pumping engine, in Clifton, Cumbria (Figure 1). Documentary evidence suggests that this engine was in use for as a little as two years. Since the site was used around the years 1780-1 it can be seen as snapshot of Newcomen engine design in the late- $18^{\text {th }}$ century. Apart from a brief summary, the details of the 1974-5 excavations have remained unpublished. ${ }^{1}$ The current work seeks to place this rescueera excavation in the context of the development of the West Cumberland coal field and Newcomen engine use during the $18^{\text {th }}$ century.

\section{COALMINING AND THE NEWCOMEN ENGINE IN CUMBRIA}

The Reelfitz Pit colliery pumping engine was one of a number of such engines established in West Cumberland during the $18^{\text {th }}$ century (Figure 2). Despite the fact that this was one of the smallest coalfields in England its development was actively pursued by two large local landowners, the Lowthers and the Curwens, from the $17^{\text {th }}$ century onwards. The early market for this coal was Ireland and later Cumbria's iron and steel industries. The drive to maximise the income and profits from this small coal field meant that technical innovation arrived early compared to the larger Lancashire coalfield to the south, allowing output to catch-up with and match the larger coalfield in the first half of the $18^{\text {th }}$ century. ${ }^{2}$ Both, however, were outstripped in terms of innovation and output by the NorthEast coalfield. This was the largest in Britain during the $17^{\text {th }}$ and $18^{\text {th }}$ centuries. It accounted in the first half of the $18^{\text {th }}$ century for $43 \%$ of Britain's coal output and in the second half for $32 \%$ as opposed to West Cumberland's $3.8 \%$ and $4.2 \%$ respectively. ${ }^{3}$ Although the last coal mine in Cumbria closed in 1983 the industry's impact on the landscape can still be seen in the creation of Whitehaven, a planned port town specialising in coal, built by the Lowthers in the $17^{\text {th }}$ and $18^{\text {th }}$ centuries, and in the 
large number of above-ground coal mining remains at colliery sites such as Saltom and Wellington pits in Whitehaven and Parton pit: rare examples in the $21^{\text {st }}$ century English countryside.

Five steam engines are recorded in the West Cumberland coal field during the first half of the $18^{\text {th }}$ century. The earliest engine used to pump water out of a Cumbrian coal mine appears to have been the well attested Newcomen engine erected in 1715-16 for Sir James Lowther at Whitehaven in Cumbria. It is described in the original agreement as a fire engine with a steam barrel of at least 17 inches $(0.43 \mathrm{~m})$ diameter and eight feet $(2.4 \mathrm{~m})$ in length. According to Hutchinson's History of Cumberland (1794) the key parts of the engine were manufactured in London and sent by sea to Whitehaven, and then erected at Stone Pit, Howgill, near Whitehaven. A premium of $£ 182$ per annum was payable to the partners. At this date the coal mine had reached a depth of 50 fathoms (c. $45 \mathrm{~m}$ ). ${ }^{4}$ The engine was used to lift the water as far as an adit or sough at an intermediate level. Trouble with roof falls, pump trees leaking and corroded copper and iron boilers all resulted in a replacement for this engine in 1726. The construction of the new engine was supervised by John and Carlisle Spedding, agents to Lowther.

There followed, in 1729-31, the erection of a pair of atmospheric engines at Saltom Pit. This, as Dr J D Marshall pointed out, involved pumping from a new and unprecedented depth of 456 feet $(137 \mathrm{~m})$, and also the commencement of undersea mining. Here at Saltom the pithead complex stood on a rock platform between the cliffs and the shore. The substantial shell of the late $18^{\text {th }}$ century winding engine house remains on site together with part of the contemporary sea wall and evidence of a gin or wooden horse wheel which was employed to wind the coal in 'corves', the local name for a basket, which each weighed 2.5 hundred weight, to the top of the cliff. Here the coal was tipped into 44hundred-weight cauldron wagons to be carted to the harbour on wooden rails and delivered to staithes. The first Saltom pumping engine stood a few metres west-north-west of the shaft and had a twelvefoot-long iron boiler, a 17 inch $(0.43 \mathrm{~m})$ cylinder, and seven-inch square pump rods. The water was lifted in four stages by the use of cisterns. A second engine was added in 1739 which had a 42 inch $(1.05 \mathrm{~m})$ diameter cylinder. Later, in 1782 both these engines were replaced by a new giant engine fitted with a 79 inch $(1.98 \mathrm{~m})$ cylinder. This engine had a six foot stroke and was also supplied with an air pump three foot $(0.9 \mathrm{~m})$ in diameter. The beam was of oak, 24 feet three inches long $(7.28 \mathrm{~m})$ and 21 inches (0.53) deep. The pump rods were twelve inches square and the steam was raised in three malleable iron boilers each of thirteen feet six inches $(4.05 \mathrm{~m})$ diameter and nine feet four inches $(2.80 \mathrm{~m})$ high with hemi-spherical tops: haystack boilers. ${ }^{5}$ Elsewhere in Whitehaven a steam pumping engine with a 38 inch $(0.96 \mathrm{~m})$ cylinder was erected at the Ginns in 1736. By 1755, the Lowther's Whitehaven pits had reached a depth of $240 \mathrm{~m}$ and their drainage employed four Newcomen engines: 'Pumps moved by rods from ponderous beams arrest the unsuspecting streams' wrote Dr John Dalton in a poem celebrating these feats. ${ }^{6}$

William Brown listed seven colliery pumping engines as working in the West Cumberland coal field during the late $18^{\text {th }}$ century: one at Workington, where there was an engine with a 28 inch $(0.7 \mathrm{~m})$ diameter cylinder; one at Greysouthen where there was an engine with a 24 inch $(0.6 \mathrm{~m})$ diameter cylinder; four pumping engines at Whitehaven with cylinder dimensions of 28 inches $(0.7 \mathrm{~m}), 36$ inches $(0.9 \mathrm{~m})$, and two at 42 inches $(1.05 \mathrm{~m})$; and one at Parton of 42 inch $(1.05 \mathrm{~m})$ cylinder diameter. ${ }^{7}$ In the 1780s Boulton and Watt steam engines were introduced as winding engines. The earliest direct application of steam power to winding was at the Crowther's Hope Pit in Workington in 1788. More Boulton and Watt engines followed; a winding engine was erected at Lady Pit in 1793 and a pumping engine in 1795 at the same site, and by 1800 there were five engines by these Birmingham manufacturers at work in the West Cumberland coal field. 
There were also local manufacturers. The Seaton Ironworks of Hicks, Spedding \& Co. near Workington (founded in 1762) manufactured a Heslop-patented engine in the 1790s and this was installed for winding in several Cumbrian collieries. The earliest appears to have been Kells Pit in 1793, followed by Davy Pit in 1794, and Lady Pit in $1795 .{ }^{8}$ Whilst the West Cumbrian coalfield's output continued to rise, and innovation was still a feature (one of the late $18^{\text {th }}$ century engines at Whitehaven may have been located underground) its proportion of the national coal supply fell steadily so that by 1800 it accounted for just 3.3\% of Britain's annual output. The survival of mining into the late $20^{\text {th }}$ century (the last pit closing in 1983) was down to highly localised needs which are beyond the scope of the current paper.

\section{THE CLIFTON COLLERIES AND THE REELFITZ ENGINE}

Reelfitz Pit (NY 0580 2968; Figure 2) lies on the western bank of the River Marron in the parish of Little Clifton, north of Bridgefoot, a pleasant riverside village on the main road between Cockermouth and Workington in northern Cumbria. The river Marron powered a corn mill in the post-medieval era and downstream of its confluence with a side stream turned a waterwheel that powered the Reelfitz Forge, where spades and shovels were made in the $18^{\text {th }}$ and $19^{\text {th }}$ centuries. ${ }^{9}$ Other industries in the Little Clifton township during this period included coal and iron ore mining, quarrying and brick making, whilst on the opposite, eastern, bank of the river lay Linefitts Colliery.

Coal was worked at Clifton in the property of the Curwens as early as 1673 . However, extensive mining had to wait until the Cooksons and Lowthers began to work adits at the Bridgefoot mine, beside the river Marron, in the area near Bridgefoot, Workington, in the mid- $18^{\text {th }}$ century. These pits became known as the Reelfitz Colliery. There are a number of shafts in this area and of these one of them reached the 'metal' and 'main' bands of coal by 1761 at a depth of 34 fathoms (30.6m).

Pumping from the Reelfitz mine was at first accomplished by water power and the coals drawn by horse gin. However, when the pit was expanded in 1780 two atmospheric engines were installed; one at Reelfitz pit (this was the engine site excavated in 1974-75) and a second at a neighbouring mine at Little Clifton. By this date Sir James Lowther had constructed a wooden waggonway down the Derwent Valley to the harbour at Workington for transporting the coal from his pits around Bridgefoot and Clifton. The pits around Clifton yielded over two million tons of coal between 1761 and $1781 .^{10}$

Despite this large scale investment the whole of the Clifton undertaking was abandoned in 1781, ostensibly following a disagreement about the inclusion of a clause in the original 1763 lease relating to the Spedding, Hicks \& Company iron works at Seaton. ${ }^{11}$ This clause, which had been arranged by Lowther's own agent, Mr Spedding who was also a partner in the iron works, required Sir James to sell coal to Spedding, Hicks \& Company at a price lower than he could have obtained by selling it at landsale prices from all his pits within $6.4 \mathrm{~km}$ (four miles) of the ironworks. In order to stop this exploitation Lowther closed all his pits within this area, at Clifton, Flimby and Seaton. As a consequence those collieries run by the Cookson family at Clifton and Greysouthen were flooded by the water previously removed through Lowther's pits and these had to be abandoned as well.

Mining continued in the immediate vicinity, although it would be 22 years before it returned to Clifton. In James Bateman's Viewer's Report Book of $1791^{12}$ there is a reference to a new engine that would pump for the little Clifton Colliery on the east side of 'the dyke', that is on the opposite side of the River Marron to the site of Reelfitz Pit. He also describes the construction of a bridge over the River Derwent for a waggonway to Workington and the expense of maintaining this. Coal mining continued in the area into the mid- $19^{\text {th }}$ century and in 1855 the Whitehaven, Cleator and Egremont 
Railway built a branch line along the Marron valley to join the Cockermouth and Workington Railway which ran through the Derwent valley to service these. The line of the branch ran immediately to the east of Reelfitz Pit before crossing the river Marron. It was progressively closed in the 1950s and 1960s.

After its closure in 1781 parts of the Reelfitz engine, including the cylinder, were left lying abandoned on the site. This is extremely surprising since it was common practice in the $18^{\text {th }}$ and early $19^{\text {th }}$ centuries to re-use such atmospheric engine parts on other colliery sites due to the cost and difficulty of manufacture. It seems unlikely that the Reelfitz Pit engine parts were abandoned in a fit of pique or revenge by Lowther, and there is archaeological evidence for another explanation (see below). During the $19^{\text {th }}$ century various writers of local histories commented on the remains lying on the surface. In 1918 the top c. 10m of the shaft had to be refilled because the soil had sunk. Unfortunately for future industrial archaeologists the opportunity was taken to tip the cylinder down the shaft as part of the new backfilling, and the site levelled, although as it transpired not all of the surviving engine parts had been lost (Figure 3). ${ }^{13}$

\section{THE EXCAVATIONS IN 1974 AND 1975}

In $1973 \mathrm{Mr}$ Bacon of the University of Manchester Institute of Science and Technology brought the existence of surviving ground remains at Reelfitz Pit to the attention of members of the Manchester Region Industrial Archaeology Society (MRIAS). These remains included engine house walls and a cast-iron disc with a large crack running across all but the last $25 \mathrm{~mm}$ of its diameter. A preliminary inspection of the site in May 1974 by members of MRIAS showed that this cast-iron disc was a piston flange of 60 inches or $1.5 \mathrm{~m}$ in diameter. In the centre was a boss with a tapered hole, to fit the piston rod, while a short distance in from the edge was a cast rung to provide support for the packing. There were also four eyes through which pivoted wrought-iron rings for lifting and assembling the object. ${ }^{14}$

Since the site was threatened by the imminent construction of by-pass bridge works a programme of rescue excavation was quickly arranged. The excavation took place in May and July 1975 and was undertaken using students from Manchester Polytechnic. ${ }^{15}$ Tarmac Ltd, who at the time had the contract for the new bypass around the village (now the A66) assisted with the loan of a JCB digger to remove the overburden (Figure 4). However, there was not enough time to strip the eastern end of the site where the rubble was especially deep. Later the site was buried under landscaping and embankment work along the southern edge of the new road and the new bridge across the river Marron.

Before excavation the site of the shaft was investigated and found to have sunk sufficiently to reveal part of the lining and the entrance to a sough close to the top (Figure 5). For safety reasons no attempt was made to dig the shaft nor to enter the depressed area, so that no accurate dimensions were obtained. However, it is known that the Lowthers built shafts with oval cross-sections and this example appeared to be roughly $2.4 \mathrm{~m}$ by $3.6 \mathrm{~m}$. The drainage sough was $1.05 \mathrm{~m}$ high and tapered from $0.9 \mathrm{~m}$ at the bottom to $0.75 \mathrm{~m}$ at the top. It was stone lined. The river had washed the bank away at the far end, when the outlet was $1.8 \mathrm{~m}$ above normal river level.

The excavations took the form of a strip-and-plan operation with the outline of the engine house, flanked by two boiler houses, being revealed (Figure 6). The remains of the complex were found to be buried beneath a demolition layer (context 002), in places more than $2 \mathrm{~m}$ high, comprising stone rubble and lime mortar. The engine house (Figure 7) was $7.44 \mathrm{~m}$ by $5.5 \mathrm{~m}$ ( $24 \mathrm{ft} 10$ " x $18 \mathrm{ft} 4$ ") in plan and was built from random masonry. The western (003) and eastern (004) walls of the engine house 
were $0.53 \mathrm{~m}$ (one foot nine inches) wide. The northern beam wall (005), opposite the pit shaft, was $1.8 \mathrm{~m}$ (six feet) thick. Although no evidence was found for the beam, other than the increased thickness of beam wall, the position of the cylinder base and the pit shaft suggested that the beam was c. $7.2 \mathrm{~m}$ (24ft) in length. This measurement places the ends of the arch heads over the pit shaft and over the end of the base for the cylinder in the engine house. Amongst the demolition layer within the engine house was an iron linkage for the piston rod, from the link and motion arrangement (Figure 8). This was discovered on the western edge of the floor of the engine house (006) adjacent to the remains of the western wall (003). It was buried beneath stone rubble and lime mortar (002) from the demolition suggesting that parts of the atmospheric engine were still in place when the site was destroyed. One of the lugs through which the pin fitted to secure the chain links from the main beam was found to be broken in antiquity, though whether during use, dismantling or as a result of the demolition was unclear. ${ }^{16}$

In contrast with the rest of the foundations the square-plan stonework (007), c. 1.5m (five feet) square, that formed the foundation for the central cylinder base was found to be poorly made and inadequately bonded to the side walls (Figure 9) and merely rubble-filled. The southern end and south-eastern corner of the engine house was filled with pebbles (008) suggesting that there might have been a soak-away in this area. Further excavation revealed the presence of a drain (009) running from underneath the cylinder base southwards to a sluice and main drain (010) that connected the western and eastern boiler houses.

The eastern boiler house (contexts 019, 020 and 021; Figure 10) was truncated by the course of the river Marron. Although only partially excavated, this was also a rectangular stone structure, $5.9 \mathrm{~m}$ by $9 \mathrm{~m}$ with a northern square chimney $(2.25 \mathrm{~m}$ by $1.75 \mathrm{~m})$ built into the fabric. This had in the middle, stretching towards the north or rear, an area of rough-cut stone slabs (012) covered with ash (011). The stones were discoloured by heat. This appeared to represent the bottom of a flue. Any further traces of the flues around the boiler and into the chimney had been removed during demolition. In front of this flue was a brick-lined pit (013) which was interpreted as a fire pit or furnace area. This feature was $1.2 \mathrm{~m}$ (four feet) across and $3.6 \mathrm{~m}$ (twelve feet) long and $1.35 \mathrm{~m}$ (four feet six inches) deep. At the end under the boiler a culvert (014) led away to the sough from the pit. It sloped down to the south, joined it in a step and at a slight angle so that it must have been designed to drain into the sough and not be fed by water from it. The pit (013) had a brick floor (017), which was covered with ash and clinker (015).

The other end of the pit had a stone flagged floor (018), which was buried in slack coal (016). The top was level with a floor of neatly squared stone slabs, which were also covered with coal. A ledge cut along the end of the stone paving suggested that the pit at this point was covered with metal plates or wooden boards. It would seem that this area was the firing platform and that coal was stacked on the stone flags ready for use at the time of abandonment. The stone wall which must have formed the front of the boiler was arced slightly from the stokehole.

The western boiler house was a rectangular stone structure, $5.9 \mathrm{~m}$ by $9.17 \mathrm{~m}$ (contexts 022,023 and 024) with a northern square chimney $(025), 2.25 \mathrm{~m}$ by $1.75 \mathrm{~m}$, built into the structure (Figure 11$)$. The fire pit (026) in the western boiler house had a similar design, fabric and size to the eastern one, being $1.25 \mathrm{~m}$ wide although its length was not determined. Both boiler houses were linked via a stone-lined drain (027) which joined the fire pits. A slot (028) for a sluice gate was found in middle of the drain (Figure 12). Just beyond the sluice this main drain was joined by a second drain from the cylinder pit in the engine house to the north. The sluice, when down, would have held back the condensated water from the cylinder so that it filled the western fire pit. When the sluice was up the water would have 
flown through the eastern pit and so into the sough. No sluice was located in the eastern boiler house to control the flow, although there might have been something by the sough entrance, an area not excavated. These drains were used to fill the fire pits with water to quench the ashes and fire falling through the bars. The excavation revealed that the floor of both fire pits was covered almost entirely in fine slack coal, demonstrating that the atmospheric pumping engine burnt unsalable coal from the pit. Ash and clinker deposits were discovered in the drains and the sough, but it was impossible to determine whether this had been swept here by the natural flow of the water or whether these deposits were the result of flushing from the pits. Washing the ash away with the condensate or the water from cleaning the boilers would have been an easy way of disposing of it but a pile of ash was found in a corner of the western boiler house suggesting that some at least was removed manually.

Within the western boiler house, adjacent to the fire pit, were found two iron bars, both $1.5 \mathrm{~m}$ (five feet) long. One was $0.15 \mathrm{~m}$ (six inches) square while the other had rectangular ends and a diamondshaped section in the centre. These fitted across the pit and must have supported the fire bars. Their positions or height from the floor could not be determined from the surviving brickwork nor could it be seen whether the grates were flat or sloping.

The areas of stone paving for the coal were separated by a cobbled section (029) in which the sluice was set (Figure 13). The top of the sluice and likewise the drain behind the cylinder, must have had some form of cover let in to the cobbles. At the front of this area was a wide doorway (030), probably the main entrance for coal and everything else for it lines up with another doorway of the same width into the engine house. The cobbles extended through into the engine house itself.

\section{THE SURVIVING $18^{\mathrm{TH}}$ CENTURY NEWCOMEN ENGINES AND REELFITZ PIT}

Estimates, based upon secure documentary and archaeological evidence, suggest that at least 2191 stationary steam engines were built during the $18^{\text {th }}$ century in Britain. This number could be considerably larger, although the figures are confused by poor contemporary descriptions and by the frequent re-use of engines and engine parts. ${ }^{17}$ Of these engines around 451 were built by Boulton and Watt, meaning that at least $80 \%$ of these machines used designs based upon Newcomen's. ${ }^{18}$ In contrast very few $18^{\text {th }}$ century stationary engines survive and an equally small number of these engine sites have been excavated in Britain. One the few areas where there has been a systematic attempt to investigate these early sites is Manchester. This town had the second largest concentration of Boulton and Watt steam engines in 1800, at 44 engines, after London (with 54). At least a further dozen engines were built by other manufacturers, mostly the Salford engineers Bateman and Sherratt who were working in the 1790s on Newcomen and Boulton and Watt hybrid designs. Hunt of London is also known to have supplied Newcomen-hybrid engines to Manchester mill owners for pumping. Five of these sites have been studied through excavation with varying degrees of success and only one of these was a pumping engine and none produced significant engine parts. ${ }^{19}$ The survival of any early stationary steam engine is thus exceptional, as is the archaeological investigation of these sites and the discovery of contemporary engine parts.

The engine parts recovered from the Reelfitz Pit engine house were the piston flange from the cylinder (Figures 3 and 14), the connecting link from the piston rod to the beam (Figure 8) and one of the chain links which fitted into the piston head. These fragments are a notable addition to the existing list of surviving $18^{\text {th }}$ century engines. Perrett lists seven Newcomen pumping colliery engines surviving in various states of completeness from the period 1725 to $1800 .{ }^{20}$ The earliest colliery pumping engine is the Dartmouth Engine (or Coventry Canal engine), originally built in 1725 for Griff Colliery north of Coventry, and moved to Measham Colliery in 1731 and then the Coventry 
Canal in 1821. It was finally moved to Devon in 1963 where it was restored. The next is the Fairbottom Bobs engine, from Park Bridge, Ashton-under-Lyne. The precise origins of this engine are unclear and it is possible, though by no means certain, that it came from Norbury, Cheshire in the 1760s. It was certainly at Park Bridge in 1776 and perhaps as early as 1765 and worked until c. 1826. The engine was removed to Dearborn, Michigan, USA in 1929 where it is on display and the site excavated in 1999. ${ }^{21}$ The Pentrich Colliery engine dates from 1791 and is the most complete of these early engines. It was built by Francis Thompson for the Oakethorpe Colliery, Alfreton, Derbyshire. It was re-erected at Pentrich Colliery in Ripley in 1841 where the engine worked until 1918. It was moved to the Science Museum in London in 1920. Another largely complete example is the Elsecar Pumping Engine. ${ }^{22}$ This is the earliest engine to remain on its original site, where it was erected in a large engine house in 1796 for Earl Fitzwilliam's Elsecar Colliery south of Barnsley, Yorkshire. It ran until 1937. The Heslop Engine was erected in 1793 at the Kells Pit at Whitehaven. It acted as both a pumping and a winding engine and is traditionally viewed as Cumbria's oldest surviving steam engine. It was a hybrid design incorporating a single-acting, high-pressure, cylinder of 34 inch $(0.84 \mathrm{~m})$ diameter and a Newcomen cylinder of 25 inch diameter to a design patented by Adam Heslop, issued in 1790. It was later moved to other local pits and in 1878 was given to the Science Museum in London. The Moira Colliery engine was built for Moira Colliery in Leicestershire in 1800. It used the crank patented by James Pickard to provide rotary motion and like Fairbottom Bobs was shipped to the USA in 1929 and is on display at the Dearborn Museum. Finally, the Windmill End Engine from Netherton, Dudley, was also a rotative engine. This was built in 1800 and was also removed to the USA. What is common to all except one of these engines is the re-use and relocation of the engines. This reflected the technical difficulties and expense in creating them in the first place: until mass-engine production in the mid- $19^{\text {th }}$ century they were too expense not to re-cycle.

The surviving Newcomen engines and the excavated pumping engine sites thus represent a tiny number of the sites built during $18^{\text {th }}$ century. It is not surprising, therefore, that the surviving engine examples have been modified by the substitution of cast-iron beams, the addition of condensers and the insertion of new valves. Even the upstanding engine house remains have been modified by later activity or conversion to an alternative use. Likewise, the excavated $18^{\text {th }}$ century engine sites have produced fragmentary or heavily altered $18^{\text {th }}$ century plans with little or no machinery surviving onsite. In contrast, the Reelfitz Pit remains have provided a near-complete excavated plan with significant engine parts remaining on-site. The only element lacking was substantial upstanding remains of the engine house.

\section{DISCUSSION}

The survival of Newcomen engine parts from the 1780s and the excavation of a complete engine house plan at Reelfitz Pit are exceptional. This discovery provides an opportunity to compare the arrangement and plan-form of these remains with the surviving engine house examples and with the most complete British excavation of an $18^{\text {th }}$-century Newcomen site - Fairbottom Bobs.

A small group of upstanding $18^{\text {th }}$-century pumping engine houses survives. ${ }^{23}$ Bick listed sixteen examples known in 1999 from Britain, although there may well be more, unrecognised due to later alteration or domestic conversion. His study was wider than this, including all of the known surviving Pre-Cornish pumping engines houses in Britain, at the time some 40 sites. Bick's observations on the development of the engine house in the $18^{\text {th }}$ century are directly relevant to the remains at Reelfitz Pit. Not only does he observe that the multi-storey structure formed an integral part of the whole machine but he also notes the impact of the technological changes of the later $18^{\text {th }}$ century on the engine house design and how these are expressed in the fabric of the building. Thus, moving the boiler outside the 
engine house, which occurred in designs from 1745 onwards, led to a reduction in the height and width of engine houses and in a new floor plan with the cylinder often sitting on the ground floor. Yet, Newcomen engines with a boiler beneath the cylinder continued to be built until around 1800, meaning that the two plan-forms of internal and external boiler engine design ran parallel for many decades. Later developments by Watt such as the introduction of a condenser after 1765 and a flywheel from the 1780s also led to changes in the plan-form and fabric of the pumping engine house.

The engine pumping house remains at Reelfitz Pit survived well enough to suggest not only its planform (Figure 6) but also its likely original appearance. Its plan ratio of 1.35 and its bob-wall ratio of 1.2 fit into the range of sizes observed by Bick from surviving pumping engine house sites of the period. In other words the design of the engine house was not exceptional for the late $18^{\text {th }}$ century. The lack of a cellar in the engine house suggests that the cylinder sat on the ground floor and that upper structure was probably no more than three storeys high. The engine house thus reflected the technological changes of the mid- $18^{\text {th }}$ century seen in Newcomen engine design. The presence of two separate boiler houses was unusual but not exceptional. ${ }^{24}$

A comparison with the Fairbottom Bobs excavation reveals a number of significant differences in their engine and boiler arrangements. The Fairbottom Bobs engine was built during the years 1765 to 1776 to an external boiler engine design like that at Reelfitz Pit. ${ }^{25}$ In this case a single haystack boiler was located to the south of the pumping engine although this was replaced by a wagon boiler around 1800. The engine itself lacked an engine house. Instead a masonry pillar supported the beam, and although unusual this was not an exceptional design approach. At Reelfitz Pit, which was built in the years 1780-1, the site used a narrow engine house design with a beam wall (Figure 15) flanked by two boilers, and the boilers, almost certainly haystack types, used a single chimney. At Fairbottom Bobs the cylinder was raised on beams over a pit. At Reelfitz, although the engine house floor was excavated and the foundations of a composite cylinder base located (Figure 7), no archaeological evidence was found to show how the bottom of the cylinder was secured to this base. The evidence was probably removed during demolition. These differences in engine and plan arrangements are a reminder of the craft nature of individual steam engine manufacture during the $18^{\text {th }}$ century.

The archaeological evidence may also provide an answer to the biggest puzzle uncovered at Reelfitz Pit - why when the site was abandoned in 1781 were the most valuable parts of the engine (the cylinder and piston flange) left on site? The excavated material suggests that a catastrophic event occurred that led to the abandoning in haste of the Reelfitz Pit engine and its engine house. Firstly, large amounts of coal were found on the floors of the boiler houses as well as ashes in their fire pits. This suggests that neither had been cleaned after final firing. Secondly, it would appear that the engine was abandoned in the engine house. The cylinder is recorded as being upstanding until its disposal in 1918, and the piston flange and piston rod link were found at the engine house site in 1975. The re-use of steam engines was so common during the $18^{\text {th }}$ and early $19^{\text {th }}$ centuries, and is so well attested from the seven surviving engine examples discussed above, as to make this occurrence highly surprising. Thirdly, the piston flange (Figure 14) and the connecting link from the piston rod both show historic damage. Together this evidence suggests that there was an accident in which some of the major parts of the engine, including the cylinder, were damaged and therefore not worth recovering for re-use. Dr Richard Hills has suggested ${ }^{26}$ that the lack of a secure cylinder base could have led to the failure of the engine and ultimately the flooding of the mine. Could the cylinder have shifted on its inadequate foundations? Unfortunately the archaeological evidence for the cylinder base did not survive intact to tell the story of the final moments of the Reelfitz Pit engine. 


\section{ACKNOWLEDGEMENTS}

The Reelfitz Pit dig was generously supported by the late Mr Wilson, a local resident. It was very much an excavation of the period - as a rescue-dig the only paid staff were the lecturers, and the excavation team comprised volunteers from MRIAS and polytechnic students. The costs of the work and site insurance were underwritten by that pioneer of the history of science and technology Prof Donald Cardwell of UMIST, who was also a founder of the Museum of Science and Industry in Manchester. The Manchester team liaised directly with the on-site contractors, Tarmac Ltd, and also with the Cumbrian county archaeologist, Tom Clare. Finally, we are grateful to Dr Richard L Hills for helping with the post-excavation interpretation of the arrangement of the engine and for highlighting the historic damage on the surviving engine parts.

\section{NOTES AND REFERENCES}

1. Rolt, L. T. C, Thomas Newcomen: the Prehistory of the Steam Engine, (London: 1963); Bick, D., 'Evolution of the Pre-Cornish Beam Engine House', Industrial Archaeology Review XXI.2 (1999), 117-36; Gould S. \& Cranston D., Monuments Protection Programme: The Coal Industry. Step 1 report. (London: English Heritage, 1992); a summary of the excavation was published in 2010 George A. D., 'Reelfitz Pit engine', The Cumbria Industrialist 7 (2010), 3-14; Allen, J. S., 'The 1715 and other Newcomen Engines at Whitehaven, Cumberland', Transactions of the Newcomen Society XLV (1972-3), 251; the photographs of the Reelfitz Pit rescue dig can be found in Chetham's Library under Manchester Region Industrial Archaeology Society Archive/3 Surveys and research/Box 4/4 Reelfitz pit engine dig.

2. Wood, O., West Cumberland Coal 1600-1982/3. Cumberland \& Westmorland Antiquarian and Archaeological Society Extra Series XXIV, (1988), 327.

3. Jones, C., 1988, 'Coal, Gas and Electricity', in Pope R., (ed.), Atlas of British Social and Economic History since c. 1700, (London: 1988), 68-81.

4. Wood op. cit p. 40; Marshall, J. D., Old Lakeland. (London: 1972), 61-75.

5. Marshall J. D. \& Davies-Shiel M., The Industrial Archaeology of the Lake Counties and Furness. (London: 1965), 109-114; Ward J., 'The sinking of Saltom Pit, Whitehaven, 1729-31', Transactions of the Cumberland \& Westmorland Antiquarian \& Archaeological Society Volume XCI (1991), 12743; Wood op. cit. 40-1; Rolt op. cit.; Hay, D., 1966, A Short History of Whitehaven. (Whitehaven: 1966), 47-50 \& 54-6; the engine was finally broken up in 1866 having continued to drain the Howgill collieries.

6. Sir J Clerk: a trip to Whitehaven in 1739, reprinted in Transactions of the Cumberland \& Westmorland Antiquarian Society NS LIV; the poem can be found in Dixon, J., The Literary Life of Dr William Brownrigg, M D, FRS, to Which is Added an Account of the Coal Mines Near Whitehaven. (London: 1801).

7. Moore, R. W., 'Coal Mining', in Wilson, J., (ed.), the Victoria County History of Cumberland, Volume 2, (London: 1905).

8. Tann, J., (ed.), The Selected Papers of Boulton \& Watt, Vol. 1: The Engines Partnership, 17751825. (London: 1981); Wood op. cit. 84-5.

9. Watson, W., Cumberland's Clifton. (Carlisle: 1970). 
10. Wood op. cit. 76 .

11. Wood op. cit.

12. Held in the Cumbria Record Office, Carlisle.

13. Watson op. cit. In 1974 a local resident, Mr Wilson, recalled how the cylinder was dumped in the open shaft in 1918.

14. In order to move the flange the piece was split in half along the crack. It is now on display at the Museum of Science and Industry in Manchester.

15. Now Manchester Metropolitan University.

16. Subsequently a local resident, Mr Wilson, produced one of the chain links which fitted into the piston head and which he had been using at home as a weight.

17. Kanefsky, J. W. \& Robey, J., 'Steam engines in eighteenth-century Britain: A quantitative assessment', Technology and Culture 21:2 (1980).

18. Tann op. cit.

19. Nevell, M., 2008, Manchester. The Hidden History. (Stroud: History Press, 2008), 82-92; Miller, I. \& Wild, C., A \& G Murray and the Cotton Mills of Ancoats. (Lancaster Imprints 13. Oxford Archaeology North, 2007); Wessex Archaeology, Arkwright's Mill, NCP Car Park, Miller Street, Manchester. Archaeological Evaluation and Assessment Results. Unpublished client report by Wessex Archaeology (April 2006); Tann op cit.

20. Perrett, D., 'The Surviving Newcomen Engines', Links 221 (the Newsletter of the Newcomen Society), March 2012, 10-11. His complete list runs to nine sites spanning the years 1725 to 1811 .

21. Nevell, M., Roberts, J. \& Champness, B., 'Excavating the Iconic: The Rediscovery of the Fairbottom Bobs Colliery Pumping Engine’, Industrial Archaeology Review XXVI.2 (2004), 83-93.

22. Clayton, A. K., 'The Newcomen Engine at Elsecar', Transactions of the Newcomen Society Volume 35 (1962), 97-108.

23. Bick op. cit. 134-5.

24. Bick op. cit. The maker of the engine at Reelfitz Pit is unknown but it may have been the local firm of Spedding Hicks \& Company who built engines and boilers in the Whitehaven area from the 1760 s.

25. Nevell, Roberts \& Champness op. cit.

26. George op. cit. Although the site of the engine house has now been lost other elements of the pit complex do survive. The location of the horse gin for winding men and coals up the shaft was discovered at the time of the excavations adjacent to the shaft. Its relationship to the oval pit shaft and the sough could be studied further.

\section{NOTES ON THE CONTRBUTORS}


DAVID GEORGE is a member of the Manchester Region Industrial Archaeology Society, a former chairman of the CBA North West Industrial Archaeology Panel and a former lecturer at Manchester Polytechnic and at the University of Manchester, Department of Extramural Studies.

DR MICHAEL NEVELL is Head of Archaeology at the University of Salford and Director of the Centre for Applied Archaeology in the School of Science and Technology. He is joint editor of Industrial Archaeology Review.

Correspondence to: Centre for Applied Archaeology, College of Science and Technology, University of Salford, Salford M5 4NW, UK. Email: m.d.nevell@ salford.ac.uk

\section{FIGURES}

Fig. 1: The Location of Reelfitz Pit, Little Clifton, Cumbria, UK. The Cumberland coalfield is outlined and the chief towns of the area named.

Fig. 2: Reelfitz Pit as shown on the Ordnance Survey first edition six inch map for Cumberland, published in 1881. Inset: the distribution of the chief collieries in the Cumberland coalfield.

Fig. 3: David George surveying the piston flange at Reelfitz in 1975. It lay abandoned on the site from 1781.

Fig. 4: Clearing the demolition rubble above the western boiler house in 1975 using a digger loaned by TARMAC Ltd.

Fig. 5: The top of the Reelfitz pit shaft showing the sough or drain in the left-hand side.

Fig. 6: The excavation plan of Reelfitz Pit.

Fig. 7: Excavation of the engine house (left) and area to the south.

Fig. 8: The iron linkage for the piston rod, from the link and motion arrangement in situ during the excavation of the engine house in 1975.

Fig. 9: Detail of the eastern wall of the cylinder base during excavation. Note the composite structure.

Fig. 10: The north-eastern corner and northern chimney stack of the eastern boiler house during excavation.

Fig. 11: The stone-flagged floor of the western boiler house during excavation. Note the depth of the overburden removed from the floor.

Fig. 12: The excavated sluice pit to the south of the engine house. This is where the drains from the engine house, western and eastern boiler houses met.

Fig. 13: The drain and sluice area to the south of the engine house entrance (to the right), looking west, during excavation in 1975. 
Fig. 14: The Reelfitz Pit piston flange on display at the Museum of Science and Industry, Manchester. Note the horizontal crack across the middle.

Fig. 15: The engine arrangement at Reelftiz Pit showing the machinery parts (labelled and shaded) recovered during the excavation. 